\title{
Cataract Operated by Phacoemulsification in a Patient with Verticillata Cornea - Clinical Case
}

\author{
Camelia CONSTANTIN
}

\begin{abstract}
Introduction: I will present the case of a patient treated for several years with amiodarone for intermittent atrial fibrillation, to which, through long use, corneal and lens changes have occurred, the latter age-induced.
\end{abstract}

Keywords: cataract, phacoemulsification, verticillata cornea.

\section{Rezumat}

Voi prezenta cazul unui pacient tratat timp de mai mulți ani cu amiodaronă pentru fibrilație atrială intermitentă, la care, prin utilizare îndelungată, au avut loc modificări corneene, dar și cristaliniene, induse de vârstă.

Cuvinte cheie: cataractă operată, faco-emulsificare, cornee verticillata.

\section{CLINICAL CASE}

This is a 70-year-old urban retiree who shows up for a gradual and sharp decrease in visual acuity in both eyes for about six months.

From the patient's history we note that she is in chronic treatment with Cordarone, about 6-7 years for episodes of atrial fibrillation.

On the ophthalmological examination it is highlighted:

Visual acuity in the right eye $0.25 \%$ without correction, does not correct, and in the left eye 0.4 with correction of +1 spherical dioptria, intraocular tension of the right eye $17 \mathrm{mmHg}$, and in the left eye of $15 \mathrm{mmHg}$.

The refraction of the right eye cannot be measured due to corneal and lens opacifications, and the refraction of the left eye is $+2.75 \mathrm{D}$ spherical combined with $-0.25 \mathrm{D}$ cylindrical at 75 degrees.

The biomicroscopic examination of the anterior pole reveals in both eyes opacifications similar to spindles or spicules, in the lower half which gives the name of the verticulated cornea, as well as lens cortico-nuclear opacifications in the right eye more than in the left eye.

${ }^{1}$ Departament of Ophtalmology, „Dr. Carol Davila” Central Military Emergency University Hospital, Bucharest, Romania
Biomicroscopy of the eye in the right eye is difficult due to corneal and lens opacifications, and in the left eye a retinal angiosclerosis, with torchy vessels and arteriovenous spastic cross.

Based on the ophthalmological examination, it is diagnosticated that:

- both eyes - senile cataract, advanced right eye, evolving left eye.

- both eyes - cornea verticillata.

- both eyes - hypertensive angiopathy.

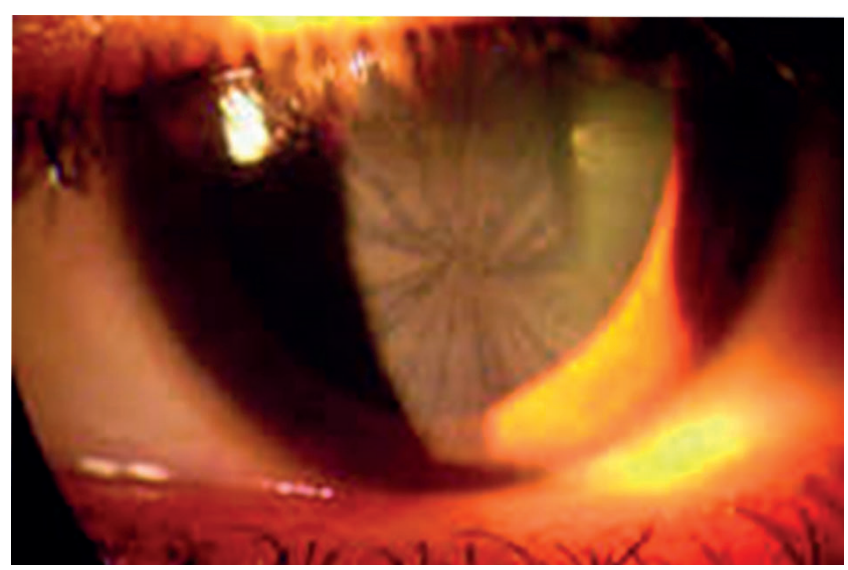

Corresponding author.

Camelia Constantin, Departament of Ophtalmology, "Dr. Carol Davila" Central Military Emergency University Hospital, 134 Calea

Plevnei, Bucharest, Romania.

E-mail: cami_nistor@yahoo.com 


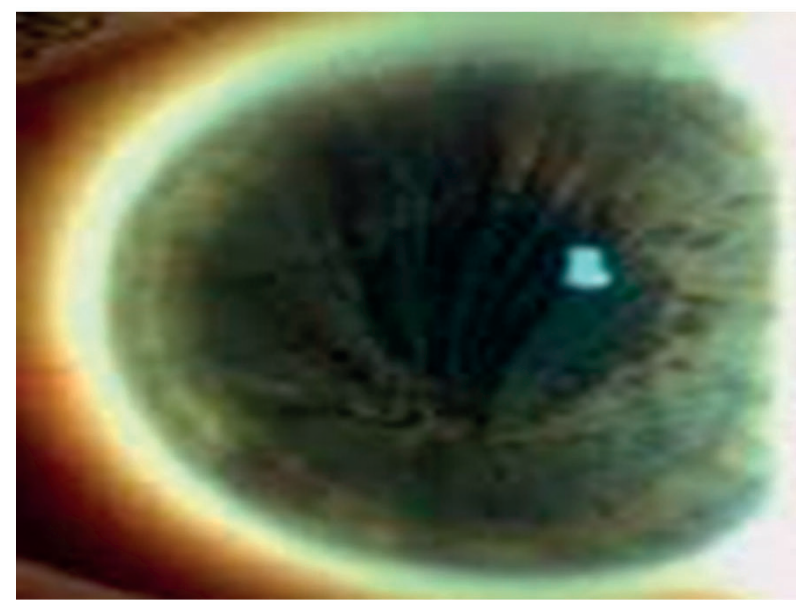

I recommended to the patient a cardiology consultation, with the indication of discontinuation of treatment with Amiodarona and a future control in one month.

On the ophthalmological examination of more than one month, it is noted the reduction of opacifications located in the cornea, so I recommend cataract surgery in the right eye.

Continue with the additional imaging investigations necessary to perform surgery on the right eye.

Specular microscopy reveals values: right eye 3140 microns, with $57 \%$ hexagonal cells, and in the left eye 2929 microns with 65\% haxagonal cells.

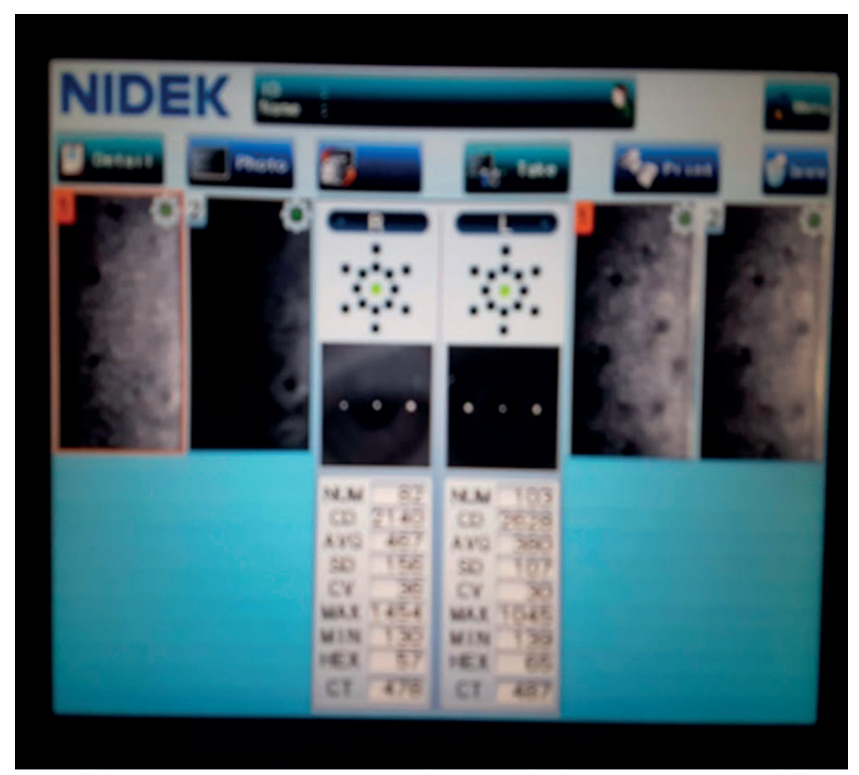

The occulto-orbital ultrasound shows the retina attached with transparent vitreous with homogeneous signal.
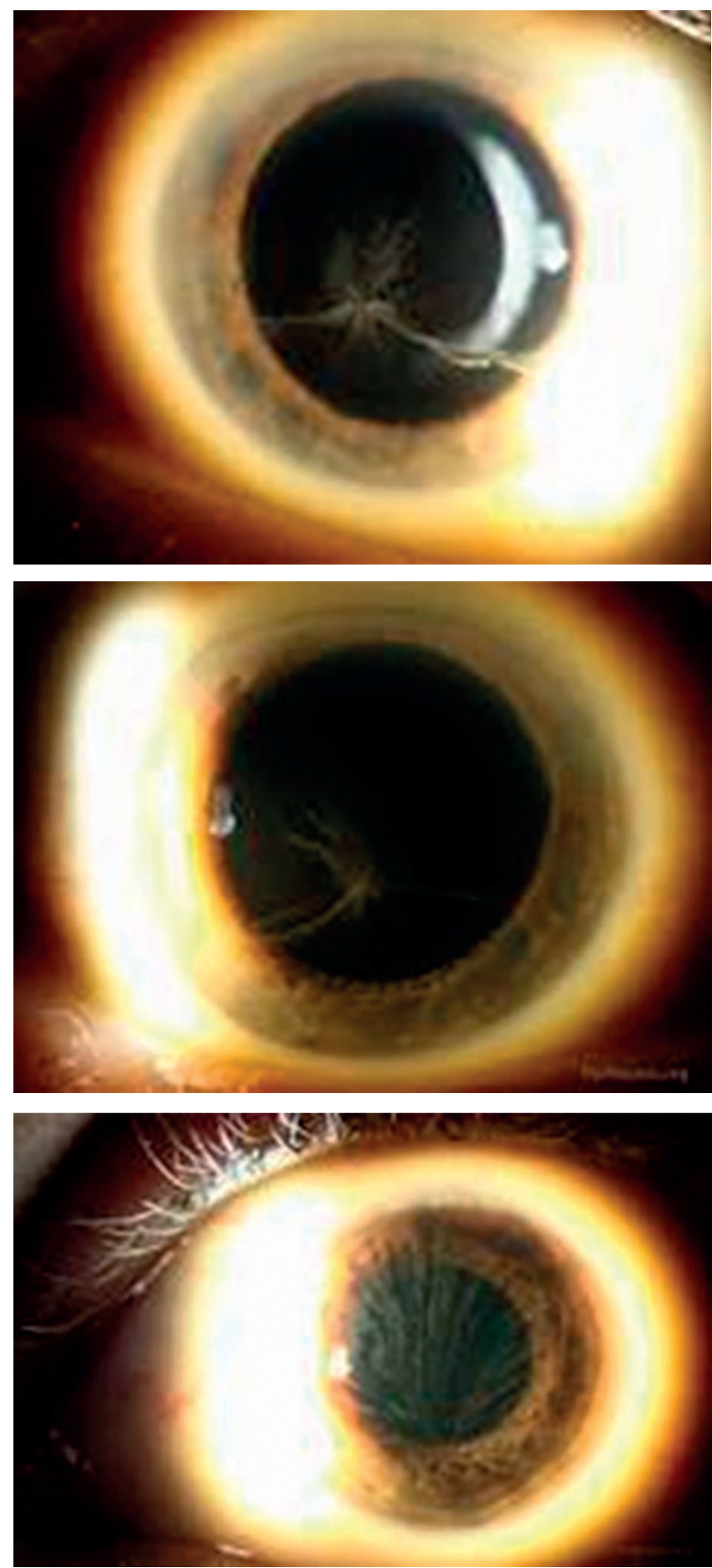

Lens biometry for the right eye 20.5/118.5 and for the left eye $21 / 118.5$.

Antero-posterior axis to the right eye $24.38 \mathrm{~mm}$ and to the left eye $24.33 \mathrm{~mm}$.

It should be noted that after performing the cardiological examination, the patient was interrupted to take amiodarone, which was replaced with Sintrom 1/2 
tablets/day. The sintrom will be interrupted 48 hours before the surgery and will be replaced with Clexane $0.4 \mathrm{mU}$ twice a day, i.e. 12 hours, with the resumption of the sintrom immediately after the surgery.

Cataract surgery with artificial posterior chamber lens implant is performed, with favorable intra- and postoperative evolution, without complications.

At the 30-day postoperative check, the visual acuity of the right eye, the operated one, was $100 \%$, and at the left eye 0.4 with correction of +1 spherical dioptria, the intraocular tension of a right eye of $17 \mathrm{mmHg}$, and the left eye $15 \mathrm{mmHg}$.

Postoperative specular microscopy is in the right eye 2551 with $67 \%$ hexagonal cells and in the left eye 2766 with $66 \%$ hexagonal cells.

Optical correction is recommended for reading and performing cataract surgery in the left eye.
The particularity of the case presented consists in the challenge of performing cataract surgery in an eye with a partially opaque cornea that gives difficulty in addressing the eye structures.

The favorable aspect of this condition, consists in reversibility when discontinuation of treatment with Cordarone.

Compliance with ethics requirements: The authors declare no conflict of interest regarding this article. The authors declare that all the procedures and experiments of this study respect the ethical standards in the Helsinki Declaration of 1975, as revised in 2008(5), as well as the national law. Informed consent was obtained from all the patients included in the study.

\section{References}

1. Jack Kanski- Clinical ophthalmology.

2. Myron Yanoff- Ophthalmology second ed.

3. International Journal of Ophthalmology, 2016. 